\title{
RELIGIOUS EDUCATION IN THE SCHOOLS
}

\section{Russell N. SullivaN*}

For many years, the courts have been trying to decide the appropriate relationship of the church and religion to the public schools and education. The dominant religious group in the community has usually pressed for the inclusion of some form of worship and religious education in the school system. This has ranged all the way from reading of the Bible as a morning exercise to direct support by tax funds of parochial schools. ${ }^{1}$. Since most of the programs express the will of the great majority of the citizens of the school districts, relatively few actions have been commenced to restrain or limit these programs. Further, since state constitutions have had the more specific provisions on the separation of church and state, few cases have reached the Supreme Court of the United States.

Beginning shortly after the turn of the century, the churches, faced with a declining attendance at the Sunday school, urged the inclusion of religious education in the school program. ${ }^{2}$ They argued that the secularization of public education results in inadequate preparation for life, for it ignores the important part which religion plays in the experience of individuals in the United States. ${ }^{3}$ Separating the teaching of religion and religious ideals entirely from the public school system and assigning this important aspect of education to after-school time or to Saturday or Sunday leads the child to regard this aspect of his education as unimportant. Thus the purpose of the weekday church school is stated by the Vermont Council of Churches as follows: "To round out a more satisfactory educational experience of the pupil by guiding him in a discovery of the spiritual and Christian elements of life." ${ }^{\prime \prime}$ The churches therefore insist that a satisfactory religious education program is one which is carried on in "public school time." This is necessary if the child is to understand the essential unity of his education and the part which religion

\footnotetext{
* Professor of Law, University of Illinois College of Law.

1 "Parochial" as used in this article means all church schools and is not limited to the Roman Catholic schools.

${ }^{2}$ Mary D. Davis, Weekday Classes in Religious Education (U. S. Office of Education, Bull. No. 3, I94I).

${ }^{3}$ See The Relation of Religion to Public Education-The Basic Principles, by thie Comaittee on Religion and Public Education of the American Council on Educuation (American Council on Education, 1946). Reprinted, 42 Religious Education 129 (1947).

- Quoted in Davis, op. cit. supra note 2, at 3 .

s'The term 'Public School Time' is used to designate the time children usually spend in the public schools. The term does not imply that school time belongs to the state; it does not imply that the state has authority to compel children to attend state schools; nor does it imply that parents may not send their children to schools other than state schools for part of, or for the entire, school timc." Jerome C. Jackson and Constantine F. Malmberg, Religious Education and the State i5 (ig28), quoted in The Week Day Church School I (Educ. Bull. No. 6or, The International Council of Religious Education, Chicago, r940).
} 
plays in it. So runs the argument of the sponsors for the weekday church schools.

The argument proved to be very persuasive. In 1946 weekday religious programs in schools were in operation in forty-six states, with an enrollment of over 2,000,000 students in more than 3000 different communities. ${ }^{6}$ In some of these states there is specific statutory authority for the program, while in others reliance is placed on a ruling of the attorney general; in still others, action of local school boards has been permitted. ${ }^{7}$ In I940, classes were held in fifty-nine different communities in New York, twenty-nine in Minnesota, twenty-three in Ohio, eighteen in Illinois, and in lesser numbers in the remaining states. ${ }^{8}$ A program so widespread clearly seerns a response to a felt need.

What is this weekday church school? To this question there is no single answer, for there are about as many differences as there are participating school systems. There are some elements of similarity which can be described. Essentially there are three different time arrangements, known as "released time," "dismissed time" and "free time." "Released time" means that the time is included in the school day and that pupils are "released" from their regular school work for a class in religious education. Students who do not attend these classes continue with other school work. "Dismissed time" describes the dismissal of the whole school from thirty to sixty minutes early one or two days a week in order that those who desire to do so may attend religious education classes. "Free time" means that the classes are conducted before or after school hours or on Saturday. Since the school cannot control the pupils' use of free time and since it seems fairly clear that the school board may authorize the shortening of one or two school days per week, "released time" is the only program the legality of which is questioned.

"Released time" classes may be conducted in church buildings, school rooms, or other buildings rented for the purpose. The essential characteristic of "released time" is that the pupil is released from his regular school work for a period of sixty minutes or less upon the written request of the parent. "Attendance is elective as far as initial choice of parents is concerned, but it is usually compulsory for all children whose parents have signed request cards for dismissal from school for religious education." The compulsory attendance makes the plan very attractive to church leaders, for it not only assures regular attendance of the pupils whose parents are anxious to have them in the classes, but it also induces other children to want to joint the classes. The advantages of "released time" are summarized as follows:

I. It is regular and not subject to competing activities, as is any other time. Even Sunday, traditionally known as "church day," is used for vacations and outings, for school and social activities.

2. It makes regular religious training a part of the child's week-day life.

${ }^{6} 24$ INT'L J. Religious Ed. 36 (April 1948).

${ }^{7}$ Davis, op. cit. supra note 2 , at 5-6. ${ }^{8}$ Id. at I3.

- The Week Day Church School, op. cit. supra note 5, at 1 . (Italics supplied.) 
3. Many unchurched children thereby receive religious training. They want to go to the church with their schoolmates and ask their parents to sign release cards. In the city of Wichita, Kansas, fully one-third of the pupils are not receiving any other religious training. ${ }^{10}$

The advantages which inhere in the use of public school rooms for the program are not essential to the success of the classes. The primary element is the use of time during the school day. If the location of the school building makes the trip to a church long or hazardous because of dangerous street crossings, attendance will be improved by securing permission to teach in the school building. Heating costs are saved, although a nominal sum may be paid for the use of school rooms to forestall the criticism that public school money is being used for religious education. Discipline is simplified, for the pupils remain in the school environment. The classes receive their largest enrollments where all of the favorable conditions are present.

A typical "released time" program was conducted in the Champaign, Illinois, public schools.' The ministers of the community formed a Council of Religious Education to prepare a curriculum to be used in the schools. All denominations and faiths were invited to participate. The Champaign Board of Education gave its consent to the use of school rooms thirty minutes each week for religious education of grade school pupils. ${ }^{11}$ The council hired a teacher to teach the Protestant classes. The classes for Catholic and for Jewish children were taught by members of the clergy when there were sufficient children to make up a class. It is important to note that there were three class groups, one for the children of each major division of the religious community. The teachers were selected and approved by the council and received no payment from the Board of Education.

The plan of operation was simple. The regular teachers during the school day explained to the children in their respective rooms that these classes would be offered and that children whose parents signed the cards would be released from regular classes to attend the religious education class thirty minutes per week. The cards were then distributed and the children were directed to take them home for their parents' signature. When the signed cards were returned, the council was advised of the number in each room and the Protestant teacher then arranged the schedule of classes. On the day and at the hour the class was scheduled, the religious education teacher came to the classroom, and if most of the students had returned cards, the religous education class was taught in that room; the regular teacher and any pupils not wishing to attend retired to some other room in the building. Some rooms had roo per cent participation in the class. During this period, the regular

${ }^{10} \mathrm{Id}$. at 15.

${ }^{11}$ The facts are summarized by the trial judge in the abstract of the record, p. 78, McCollum v. Board of Education, 396 Ill. I4, 7I N. E. 2d I6I (1947), 333 U. S. 203 (1948). Since there was no controversy over the plan, page references to the abstract will not be made for all of its details. The abstract of the record and all of the briefs in the case were supplied to the writer by Mr. John Franklin of the Champaign, Illinois, bar, counsel for the Board of Education. The briefs and discussions with Mr. Franklin contributed substantially to this paper. 
teacher did not continue to teach the regular subject matter to the children under her direction, but she gave individual help to those who needed it.

In the summer of 1945 , this plan was challenged by the mother of a boy in the fifth grade of the Champaign schools. Mrs. Vashti McCollum sought a writ of mandamus to compel the Board of Education to discontinue the teaching of religious education in the schools and to prohibit the use of the school rooms for this purpose. She alleged that the plan set out above violated the Illinois statutes, the Illinois constitution, and the Fourteenth Amendment to the United States Constitution. She charged that the program amounted to sectarian religious instruction since there were separate classes for Protestants, Catholics, and Jews. Finally, she alleged that though voluntary on its face, the plan was compulsory because her son was the only one in the room who did not enroll in the classes and, being thus singled out from his fellows, he was coerced into joining the group. The classes, although voluntary in the first instance, became compulsory for the child after the parents had signed the request for release from regular school work for that period.

Counsel for Mrs. McCollum relied heavily on Ring v. Board of Education, decided by the Illinois Supreme Court in Igro. In that case, the petitioner sought a writ of mandamus to compel the board of education to cause to be discontinued the reading of the Bible, singing of religious hymns, and reciting the Lord's prayer as regular exercises in the public schools. Since these acts all took place in the regular school time in the regular schoolroom, all of the children participated in them. The petitioner, a member of the Roman Catholic church, insisted that this amounted to religious worship in violation of the state constitution. The majority of the court decided that the reading of the Bible is sectarian, for the school authorities used the King James version, which is unacceptable to Catholics, who use the Douay version. Both of these are sectarian in the eyes of the Jews. While the majority observed that Illinois was a Christian state and the majority of the people were Protestant, one of the purposes of the constitution was to protect minorities against compulsory conformance to the wish of the majority. On the question of compulsory participation in the exercises, Justice Dunn wrote:

The Kentucky and Kansas decisions seem to consider the fact that the children of the complainants were not compelled to join in the exercises as affecting the question in some way. That suggestion seems to us to concede the position of the plaintiffs in error. The exclusion of a pupil from this part of the school exercises in which the rest of the school joins, separates him from his fellows, puts him in a class by himself, deprives him of his equality with the other pupils, subjects him to a religious stigma and places him at a disadvantage in the school, which the law never contemplated. All this is because of his religious belief. If the instruction or exercise is such that certain of the pupils must be excused from it because it is hostile to their or their parents' religious belief, then such instruction or exercise is sectarian and forbidden by the Constitution. While some of these decisions tend to sustain the proposition that the reading of the Bible, prayer, and singing of hymns in accordance with the usual method of conducting devotional exercises

${ }^{12} 245$ Ill. 334,92 N. E. 25 I (x910). 
in Protestant denominations may be required of the pupils of a public school against the protest and religious convictions of the pupils and their parents, we cannot assent to the reasoning on which such decisions are founded and apply it to the provisions of our constitution. ${ }^{13}$

The dissenting judges called attention to the provisions of the Ordinance of the Northwest Territory of $\mathrm{I}_{787}$ : "It is therein provided that 'religion, morality, and knowledge being necessary to good government and happiness of mankind, schools and the means of education shall forever be encouraged." 14 Since the high moral values of the Bible are universal, its reading in the public schools should not, they argued, be banned by the court. The dissenting judges concluded that since the Bible was not necessarily sectarian, the decision in this question should be left to the local school boards and the state constitution should not be interpreted as denying that power to the local boards.

Although the decision in this case seemed to the petitioner to support a judgment in her favor, other Illinois decisions had permitted some state aid to religion. The Illinois Supreme Court had early held that the state constitution was not violated by a school board which allowed the school building to be used for a religious meeting outside of school time. ${ }^{15}$ The financial aid was indeed slight, for it would be impossible to determine the amount of wear and tear on the schoolhouse caused by this meeting, and the aid was thought to come within the doctrine of de minimis. Attendance at the meeting was entirely voluntary; the state aid here was likened to the exemption of church property from taxation. This same rule was held applicable to the use of a part of a school building by a fraternal organization. . $^{\mathbf{1}}$

Somewhat closer to the religious education classes in the schools is the rule of the University of Illinois, a state-supported school, which required all students to attend regular chapel exercises unless they were excused. A student who refused to ask to be excused was excluded from school for wilfully absenting himself from the chapel exercises. He was out of school for two years and then petitioned for a writ of mandamus to compel the university to permit him to return. Although a majority of the court refused the writ on the ground that the regulation was reasonable, ${ }^{17}$ much stress was laid on the remedy. Even assuming that the student had a right to return to school, the court thought that there was an insufficient showing that he wanted to attend and therefore mandamus was not proper. The concurring judges relied on the latter ground. ${ }^{18}$

The use of property of religious corporations for public purposes has been litigated a number of times in Illinois. In a school district predominantly Catholic, the

\footnotetext{
${ }^{13}$ Id. at $35 \mathrm{I}, 92 \mathrm{~N}$. E. at $256-257$.

${ }^{15}$ Nichols v. School Directors, 93 Ill. 6I (1879).

14 Id. at 355,92 N. E. at 258 .

${ }^{10}$ Lagow v. Hill, 238 Ill. 428,87 N. E. 369 (1909).

${ }^{17}$ North v. Board of Trustees of University of Illinois, 137 Ill. 296,27 N. E. 54 (189r).

${ }^{18}$ In McCormick v. Burt, 95 Ill. 263 (1880), the court refused to set aside a rule of a school board requiring the reading of the King James version of the Bible as a part of the morning exercises, because the plaintiff in a suit for damages failed to allege that the board acted wantonly or maliciously.
} 
voters failed to approve a bond issue to build a school building. The board of education then rented the basement of the Catholic church for the public school. The priest held religious services in the one-half hour period prior to the school time. This arrangement was sustained, for the annual rental for the room was a reasonable fee and was therefore not an aid to religion, and there was no showing that students were compelled to attend the church services. ${ }^{19}$ The Illinois Supreme Court also. held that for the county commissioners to permit the Catholic bishop to build a' chapel for religious services on land owned by the county as a part of its poor farm did not amount to an unlawful aid to religion. ${ }^{20}$

Since the State and the counties were slow to provide homes to which children could be committed by the juvenile courts, the county commissioners often contracted with religious organizations to pay for the care and education of delinquent children. At the homes, children whose religious belief or preference was the same as that of the religious order or denomination in charge of the school were required to attend religious exercises, and others were urged to do so. This arrangement was challenged in a series of taxpayers' suits to enjoin payment of money under the contract. It was alleged that this amounted to an aid to religion. Although first' held invalid, the practice was later approved. ${ }^{21}$ The fees charged by the religious groups for the care and education of the child were so low that no profit could be made, so there was no financial aid to religion. It does seem clear, however, that the commitment to the school and compulsory attendance at religious exercises did interfere to some extent with the religious freedom of the children.

The most obvious aid to religion is the tax exemption afforded religious property. That exemption becomes a particularly valuable asset when it extends to all property owned by the religious or charitable corporations rather than only to the property used for religious or educational purposes. Even this broad exemption the Illinois Supreme Court decided was not an aid to religion. ${ }^{22}$

This was the state of the law in Illinois when People ex rel. McCollum v. Board of Education of Champaign came to trial in Champaign County. The residents of the county were sharply divided on the question, although the majority clearly favored the school board. ${ }^{23}$ Even those who believed that the program of the,

${ }^{10}$ Millard v. Board of Education, 121 Ill. 297, 10 N. E. 669 (I887).

${ }^{20}$ Reichwald v. Catholic Bishop, 258 Ill. 44, Ior N. E. 266 (r913).

${ }^{21}$ In Cook County v. Chicago Industrial School for Girls, 125 Ill. 540, I 8 N. E. 183 ( 1888 ), this practice was held invalid. Here, although the girls were committed to the defendant school, it had no property or staff, but the girls were cared for by St. Joseph's Orphan Asylum and the Sisters of the Good Shepherd. Since the Industrial School did not exist as a separate organization, the payments to it would aid religion. Contra: Dunn v. Chicago Industrial School, 280 Ill. 613, II7 N. E. 735 (1917); Dunn v. Addison Manual Training School, 28I Ill. 352, II7 N. E. 993 (19I7); Trost v. Ketteler Training School, 282 Ill. 504, x 18 N. E. 743 (r918); St. Hedwig's Industrial School v. Cook County, 289 Ill. 432, 124 N. E. 629 (1919).

${ }_{22}$ Garrett Biblical Institute v. Elmhurst State Bank; 33 I Ill. 308 , I63 N. E. I (1928). See also on the definition 'ff a religious corporation under Illinois statutes, Hamsher y. Hamsher, 132 Ill. 273,23 N.E. II23 ( 1890$)$.

${ }^{23}$ The writer was and is a resident of Urbana-Champaign and listened to and participated in con- 
school board was unconstitutional or unwise regretted that the suit was brought in the name of an avowed atheist. The case was tried before the three judges of the circuit court en banc. Unfortunately, the trial at times seemed to be a trial of religion itself and not of the validity of this program in the Champaign schools. The judges, attempting to admit in evidence any material which might be relevant, permitted an extensive inquiry into the beliefs of the petitioner and of many of the other witnesses.

The trial court found that the program was completely voluntary, that the use of the schoolrooms for the classes did not amount to financial support, and that the teachers were not paid by the school board. Even though the classes were sectarian, any group had equal access to the program and since no group was preferred, the system was valid.

On appeal to the Supreme Court of Illinois, the decision of the trial court was affirmed. ${ }^{24}$ The opinion concluded ${ }^{25}$ that this was a voluntary program of religious education. These classes did not violate the freedom of conscience of anyone or of any group. Freedom of religion was intended to mean the right of an individual to believe as he wishes without interference by the state. The state recognizes no specific religion, but it does recognize religious ideals. Justice Thompson did not discuss the sectarian issue but assumed that aid could be given to religious education so long as all were afforded equal opportunity. The opinion does not recognize the difficulties facing a minority like the Jehovah's Witnesses in securing approval of classes for the children of that sect.

Within a month after the Illinois court decided the McCollum case, the United States Supreme Court handed down the opinions in the Everson case. ${ }^{26}$ In that case the power of the board of education to pay the bus fares of school children who attend parochial schools as well as those who attend public schools was sustained. The board had authorized reimbursement to parents of money expended by them for the bus transportation of their children in regular busses operated by the public transportation system. It was admitted that the Catholic schools gave religious as well as secular instruction to their pupils.

The opinion of Justice Black first rejects the argument that taxation to pay these bus fares of children who attend Catholic schools is not a public purpose. This proposition seems to be so well established by this time that it deserves no comment here. The second point in the majority opinion relates, of course, to the validity of the New Jersey statute and its application in this case under "the establishment

siderable discussion of the merits of the lawsuit. For a time this was the principal topic of conversation in the community and the local newspapers. The Champaign-Urbana News-Gazetie and The Urbana Courier daily carried complete summaries of the trial. Much of the testimony was printed verbatim. See these papers for September 10-14, 1945.

"McCollum v. Board of Education, 396 Ill. 14, 7I N. E. 2d r6r (1947). One year earlier in Latimer v. Board of Education, 394 Ill. 228, 68 N. E. $2 d$ d05 (1946), the Chicago "relcased time" religious education program was held valid. In that case, the classes were not held in the school buildings.

${ }_{25}$ Id. at 29,71 N. E. 2 d at I64.

"Everson v. Board of Education, 330 U. S. I (1947). 
of religion" clause of the First Amendment to the United States Constitution. Justice Black concluded that this clause was intended to erect "a wall of separation between church and state" and that this provision was made applicable to the states by the due process clause of the Fourteenth Amendment. ${ }^{27}$ There is no longer any doubt that all of the guaranties of the First Amendment have been brought within the due process clause of the Fourteenth. ${ }^{28}$ These are rights fundamental to a free people. Justice Black then stated the case for separation of church and state as follows: $:^{29}$

The "establishment of religion" clause of the First Amendment means at least this: Neither a state nor the Federal Government can set up a church. Neither can pass laws which aid one religion, aid all religions, or prefer one religion over another. Neither can force nor influence a person to go to or to remain away from church against his will or force him to profess a belief or disbelief in any religion. No person can be punished for entertaining or professing religious beliefs or disbeliefs, for church attendance or nonattendance. No tax in any amount, large or small, can be levied to support any religious activities or institutions, whatever they may be called, or whatever form they may adopt to teach or practice religion. Neither a state nor the Federal Government can, openly or secretly, participate in the affairs of any religious organizations or groups and vice versa. In the words of Jefferson, the clause against establishment of religion by law was intended to erect "a wall of separation between church and State."

Such unequivocal language would seem to lead to the conclusion that the New Jersey statute was invalid. The payment of bus fares of children to attend the Catholic schools does amount to an aid to religion, for it may be the factor which induces a parent to send a child to a Catholic school. The Justice, however, decided that the aid is not to religion but to the pupil and that bus transportation is like police or fire protection which is furnished to church and parochial schools. These distinctions are not very convincing. ${ }^{30}$ And the conclusions seem inconsistent with the quoted passage. Police and fire protection are provided for all persons and property without regard to the religious affliations of the individual or property owner. Here bus fares are paid to parents who have sent their children to a Catholic school. ${ }^{31}$

${ }^{27}$ Id. at I4. In Adamson v. California, 332 U. S. 46 (1947), Justice Black in dissent insisted that the due process clause of the Fourteenth Amendment was intended to incorporate the first eight amendments. See appeadix to the dissenting opinion, 332 U. S. 92 . He argued very persuasively that the earlier cases had been based on a misunderstanding of the Fourteenth Amendment. In Palko v. Connecticut, 302 U. S. 319. (1937), Justice Cardozo had said that some of the provisions of the first eight amendments were incorporated into the Fourteenth and some were not so included. The following test for inclusion or exclusion was stated: "On which side of the line the case made out by the appellant has appropriate location must be the next inquiry and the final one. Is that kind of double jeopardy to which the statute subjected him a hardship so acute and shocking that our policy will not endure it? Does it violate those "fundamental principles of liberty and justice which lie at the base of all our civil and political institutions'?" 302 U. S. 328 .

${ }_{28}$ In Thomas v. Collins, 323 U. S. 5 r6, 531, 533 ( 1945 ), Justice Rutledge discussed the application of the First Amendment in freedom-of-speech cases.

${ }^{29}$ Everson v. Board of Education, 330 U. S. I, 15-I6 (1947).

${ }^{30}$ Justices Jackson, Rutledge, Frankfurter, and Burton dissented. Justice Rutledge makes a strong case for complete separation of church and state and insists that the payment of bus fares is an aid to religion.

${ }^{31}$ Justice Jackson, dissenting, 330 U. S. 18, 25. 
Justice Rutledge, dissenting, relied on Madison's Remonstrance and the defeat of the Virginia "Bill Establishing a Provision for Teachers of the Christian Religion" and the enactment in Virginia of a "Bill for Establishing Religious Freedom,"32 to determine the meaning of the "establishment of religion" clause of the First Amendment. The debates on this clause of the Bill of Rights were so short, he argued, as to indicate that the essential issues had been settled in Virginia. ${ }^{33}$ Accepting this history, Rutledge concluded that the Amendment had for its purpose the complete separation of church and state. ${ }^{34}$ If church and state are separated by a wall, then no state aid can be given to any religion or to all religions.

The decision in the Everson case thus added the payment of bus fares of children who attend parochial schools to the purchase by the state of school books for children in similar schools, ${ }^{35}$ as practices sanctioned by the Court under the First Amendment. In both these situations the aid was given to the pupil and not to the schools. It might be argued that the aid is de minimis; but in the protection of the great guaranties of the First Amendment, the present Court has not been willing to accept this doctrine. ${ }^{36}$

In the McCollum case, ${ }^{37}$ the Champaign program of religious education was -found by the Supreme Court of the United States to violate the principle of separation of church and state. The precise basis for the result is impossible to determine. .The Court emphasized that the property of the school was being used for religious purposes and that the compulsory attendance was a device to aid the religious classes. Justice Black states:

Here not only are the State's tax supported school buildings used for the dissemination of religious doctrines. The State also affords sectarian groups an invaluable aid in that it helps to provide pupils for the religious classes through the use of the State's compulsory. public school machinery. This is not separation of Church and State. ${ }^{38}$

Justice Frankfurter in a separate opinion reviewed the history of the secularization of the public schools prior to the adoption of the Fourteenth Amendment. ${ }^{30}$

'32 The Remonstrance and $A$ Bill Establishing a Provision for Teachers of the Christian Religion are printed as an appendix to Justice Rutledge's dissenting opinion 330 U. S. 63,72 . See also II TuE Writings of James Madison i83-19t (Hunt ed. igor).

. 3330 U. S. 42 .

s4 Jefferson's famous phrase occurs in a letter he wrote January I, I802, to a committec of the Baptist Convention in the State of Connecticut as follows: "Believing with you that religion is a matter which lies solely between man and his God, that he owes account to none other for his faith or his worship, that the legislative powers of government reach actions only, and not opinions, I contemplate with sovereign reverence that act of the whole American people which declared that their legislature should 'make no 'law respecting an establishment of religion, or prohibiting the free exercise thereof,' thus building a wall of separation between church and Staze." Saul K. Padover, The Complete Jefferson 518-519 (1943). (Italics supplied.)

${ }^{35}$ Cochran v. Board of Education, 281 U. S. 370 (1930). Justice Rutledge explained the result in this case on the ground that the petitioner did not squarely invoke the religion clause of the First Amendment. 330 U. S. 29, n. 3.

${ }^{30}$ Thomas v. Collins, supra note 28.

${ }^{57}$ McCollum v. Board of Education, 333 U. S. 203 (1948).

${ }^{58}$ Id. at 212 .

so Ibid. Justices Jackson, Rutledge, and Burton joined in this opinion. 
He made clear, however, that the decision does not have the sweep of complete prohibition of "released time" programs. Some forms of "released time" classes may be held to be constitutional. It is this which led Professor Corwin to forecast that the decision created "The Supreme Court as a National School Board."40

The lone dissenter was Justice Reed, who pointed out that Jefferson, when faced with a similar problem at the University of Virginia, believed it proper for religious exercises to be conducted in a building of the University. ${ }^{41}$ The opinion refers to the fact that both the United States Military Academy and the United States Naval Academy provide chapel and at the Military Academy attendance at religious services is compulsory. ${ }^{42}$ The use of the property of the school places no heavy burden on the taxpayer and in the Champaign case attendance at the classes was voluntary.

In the Everson and the McCollum cases, members of the Court disagreed on the history - that is, the meaning -of the phrase "establishment of religion" in the First Amendment.

It may be worth while to review decisions of a few state courts on various aspects of the problem. ${ }^{43}$ The questions involved range all the way from hiring Catholic teachers for a public school to complete tax support for a church school. For example, a school board may hire a teacher regardless of religious belief and that teacher, it has been held, if a member of a religious order, may wear the garb of her order in the classroom, ${ }^{44}$ despite the argument that the wearing of the garb is an act of religious worship which carries sectarianism into the classroom. There are conflicting decisions on whether reading of the Bible in the public schools is illegal because it constitutes sectarian instruction. ${ }^{45}$ Payments by the state to religious organizations for the care and education of orphans or the hospital care of persons with contagious disease have also resulted in conflicting decisions. ${ }^{46}$ Although state

${ }^{10}$ Corwin, The Supreme Court as National School Board, supra; see also 23 THovart 665 (I948). In addition to the practical problem created by the decision, Professor Corwin finds the historical data to lead to a contrary conclusion. He reads the history to prove that it was the intention of the amendment only to prevent the preference of one religion over another.

${ }^{\star} 333$ U. S. 245 , n. II. See also the Regulations of the University of Virginia: "One of its larger elliptical rooms on the middle floor shall be used for annual examinations, for lectures to such schools as are too numerous for their ordinary school room, and for religious worship, under the regulations allowed to be prescribed by law." Saul K. Padover, The Complete Jefferson iti (i943).

12 Id. at 254, n. 30 .

${ }^{13}$ Many of the state cases turn on particular provisions of state constitutions. They are used here only to indicate the trends in the states.

" Gerhardt v. Heid, 66 N. D. 444,267 N. W. 127 (1936); Hysong v. School Dist. of Gallitzin Borough, $164 \mathrm{~Pa}$. 629,30 Atl. 482 (1894).

${ }^{40}$ Illegal: Herold v. Parish Board of School Directors, 136 La. 1034, 68 So. II6 (1915); Weiss v. District Board, 76 Wis. 177, 44 N. W. 967 (1890); Ring v. Board, stspra note 12. Contra: Kaplan v. Independent School District, I7I Minn. I42, 214 N. W. I8 (1927).

${ }^{\circ}$ Payment valid: Bradfield v. Roberts, I75 U. S. 29I (1899); Quick Bear v. Leupp, 210 U. S. 50 (1908), Illinois cases supra note 21. Contra: Nevada Orphan Asylum v. Hallock, I6 Nev. 373 (1882); Collins v. Kephart, $27 \mathrm{I} \mathrm{Pa.} \mathrm{428,} \mathrm{II7} \mathrm{Atl.} 440$ (I92I); State v. Frazier, I02 Wash. 369, I73 Pac. 35 (1918). In the Quick Bear case, the United States Supreme Court held valid the payment of money from Indian trust funds to certain Catholic Sisters for tuition for the education of Indians on reservations. The Court assumed that regular appropriations might not be made to these organizations, but the trust funds were believed to be in a different category, even though they were held in the Treasury- 
payment of the cost of transportation to attend Catholic schools has been approved ${ }^{47}$ in accord with the Everson case, the cost of tuition at a church school, it has been held, may not be borne by the state or school district. ${ }^{48}$ This was so even though the public school in the district was closed and tuition had to be paid for pupils to attend school in another district. ${ }^{49}$ Since these funds were used to reimburse parents for money paid for the education of their children, it could well be argued in line with the Everson case that this was aid to the child and not aid to religion.

The "released time" religious education program has been litigated in a group of cases in New York. It was first enjoined, ${ }^{50}$ even though classes were not held in the school buildings, but subsequently "released time" classes were permitted under regulations promulgated by the Commissioner of Education. ${ }^{51}$ California had likewise sustained classes which were held away from school buildings, even though the school teachers did participate in the distribution of cards for the classes and in assigning the children to the correct hour and place for the classes. ${ }^{62}$ The California court recognized that the religious education was sectarian:

As the plan operates, children are segregated according to the preferences expressed by their parents regarding religious instruction, transported from the school grounds to places arranged for by the Interfaith Committee, and there taught the doctrine of the church to which they have been assigned..$^{53}$

If the state can support children in sectarian orphanages, transport them to parochial schools, and release them from a part of the regular school time for sectarian religious education, the next question is whether it may use tax funds to support sectarian schools or colleges. Many states have specific constitutional provisions which prohibit any appropriation for any sectarian purpose. These have been held to prevent financial aid to any church or private school. ${ }^{54}$ Two cases merit consideration. An lowa board of education discontinued the use of a separate public school building and leased a part of the parochial school building for public school purposes. In one room an allegedly public school was conducted,

The Court said: "Some reference is made to the Constitution, in respect to this contract with the Bureau of Catholic Indian Missions. It is not contended that it is unconstitutional, and it could not be." 2I0 U. S. 50, 8I (I908).

${ }^{47}$ Bowker v. Baker, 73 Cal. App. 2d 653, 167 P. 2d 256 (1946). Contra: Judd v. Board of Education, 278 N. Y. 200 , I5 N. E. 2 d 576 (1938).

${ }^{48}$ Synod of Dakota v. State, 2 S. D. 366, 50 N. W. 632 (r89r); Hlebanja v. Brewe, 58 S. D. 35r, 236 N. W. 296 (I93I).

to Hlebanja v. Brewe, supra.

${ }^{50}$ Stein v. Brown, 125 Misc. 692, 211 N. Y. Supp. 822 (1925).

${ }^{62}$ Lewis v. Graves, 127 Misc. 135, 215 N. Y. Supp, 632 (1926), 219 App. Div. 233, 219 N. Y. Supp. 189 (1927), 245 N. Y. 195, 156 N. E. 663 (1927). Reading of the Bible in New York schools was likewise sustained in Lewis v. Board of Education, 258 N. Y. II7, 179 N. E. $3 \times 5$ (1932).

${ }^{2}$ Gordon v. Board of Education, 78 Cal. App. $2 d{ }_{46}$, 178 P. 2d 488 (1947).

${ }^{63} \mathrm{Id}$. at $465,178 \mathrm{P} .2 \mathrm{~d}$ at 489 . (Italics supplied.)

* Atchison, T. \& S. F. R. R. v. Atchison, 47 Kan. 712, 28 Pac. 1000 (1892); Williams v. Board of Trustees, I73 Ky. 708, I9r S. W. 507 (I917); Jenkins v. Andover, r03 Mass. 94 (1869); In re Opinion of the Justices, 214 Mass. 599, I02 N. E. 464 (r913); Public School District v. Taylor, r22 Neb. 454, 240 N. W. 573 (1932). 
but in the other room a parochial school was held. The school was really divided with grades one to five in one room and grades six through eight in the other. Both rooms were taught by Catholic sisters, one of whom was the public school teacher; the other was not supported by tax funds. Religious services were conducted before school began in the morning, but there was no religious education during the regular school period. It was contended that attendance at the religious service was voluntary, but the children were marched in a group to the church for that period of worship. The board of education approved the selection of the teachers and supervised the curriculum and the expenditures. This arrangement was held to constitute an abandonment of the public school and public appropriation to a parochial school, and to violate the state constitution. ${ }^{55}$ The court thought that though the church service was voluntary in plan, it would be compulsory in effect.

Conceding for argument's sake, that such attendance was voluntary, in the sense that no requirement or command was laid upon non-Catholic pupils to attend or take part in such exercises, yet, surrounded as they were by a multitude of circumstances all leading in that direction, impelled by the gregarious instincts of childhood to go with the crowd, and impressed with a sense of respect for their teachers, whose religious principles and church affliation were unceasingly pressed upon their notice by their religious dress and strictly ordered lives, could a reasonable person expect the little handful of children from non-Catholic families to do otherwise than to enter the invitingly opened door of the church, and receive, with their companions, the instructions there given? That these conditions show any real or substantial removal of the objectionable features which differentiates this school from the public school provided for by law, we cannot admit. When we speak of these matters as objectionable, it is not because of any danger of injury, moral or religious, to children of another faith, but because they cannot be tolerated in public schools without infringing upon the common right of every citizen, whatever his faith, to rear his own children in his own way, so long as he keeps within the law. ${ }^{56}$

The court accepted fully the Jeffersonian doctrine of complete separation of church and state:

If there is any one thing which is well settled in the policies and purposes of the American people as a whole, it is the fixed and unalterable determination that there shall be an absolute and unequivocal separation of church and state, and that our public school system, supported by the taxation of the property of all alike-Catholic, Protestant, Jew, Gentile, believer, and infidel-shall not be used, directly or indirectly, for religious instruction, and above all, that it shall not be made an instrumentality of proselyting influence in favor of any religious organization, sect, creed, or belief. So well is this understood, it would be a waste of time for us, at this point, to stop for specific reference to authorities or precedents, or to the familiar pages of American history bearing thereon. ${ }^{57}$

This opinion is an excellent summary of the arguments against any state support of a church school.

A contrary result was reached in a fairly recent case in Indiana. ${ }^{58}$ The parochial

\footnotetext{
E6 Knowlton v. Baumhover, 182 Iowa 691, I66 N. W. 202 (rgI8).

${ }^{00}$ Id. at $699, \mathrm{I} 66 \mathrm{~N}$. W. at 205 . ${ }_{5 \pi}$ Id. at 704, I66 N. W. at 206-207.

${ }^{68}$ Johnson v. Boyd, 217 Ind. 348,28 N. E. $2 d 256$ (x940).
} 
schools of Vincennes were about to be closed during the depression for lack of funds. The priests went to the school board and informed the board that they could no longer maintain the schools and had decided to close them. The school buildings were then offered to the board for use as public schools. The board accepted the offer and the parochial schools were incorporated into the public school system. The board then hired as public school teachers Catholic sisters and lay brothers who were recommended by the church. The curriculum of these schools was then made to conform to that of the other public schools, and no sectarian teaching was permitted during the regular school hours. The city of Vincennes was divided into school districts and children attended the school in the district in which they lived. Catholic children were not required to attend the district school but were permitted to continue at their own schools. Before school each morning all of the Catholic children were "caused" to attend mass in the adjacent church. Thus, the parochial school was continued for Catholic children, taught by the same teachers who had previously been assigned by the church, but the school board was nominally in control of the school and all the expenses were met from tax funds. The court sustained this arrangement on the ground that the board of education controlled the schools and that there was no religious instruction during school hours. The final decision on the hiring of teachers rested with the board. The fact that all of the teachers were the recommended Catholic sisters and lay brothers who wore the robes and garbs of their orders was irrelevant. On the question of attendance at the morning religious exercises the court said:

The findings do not disclose by whom the children were "caused" to attend. The finding does disclose that the service was said to be voluntary. Since the children in question were children of Catholic parents and the service was voluntary and not within the school hours we fail to see that this amounts to sectarian teaching within the schools or that it could be held to make the schools parochial schools rather than public schools.50

It is especially interesting that the court recognized that only Catholic children were in attendance at these schools and therefore that the voluntary service was probably attended by all. The very segregation of children in the public school system on the basis of religion would seem sufficient reason for invalidating this arrangement.

The foregoing summary of some of the state decisions on the separation of religion and the public schools shows that there is no unwavering support for the complete separation of church and school. Even under express state constitutional provisions some inroads were made. Thus reading the Bible in the schools was or was not constitutional; support for church hospitals or church schools was or was not within the power of the state or Federal Government; and finally a school district in Indiana could incorporate a parochial school into the public school system, but in Iowa this could not be done. It is fair to say that the policy of the states has not been clear and convincing. Although secularization of education progressed

${ }^{80}$ Id. at 372,28 N. E. 2d at 266. 
markedly in the last century, the state experience does not lead necessarily to: the result in the $\mathrm{McCollum}$ case.

The policy of the states being doubtful, the historical argument must be examined. Justice Rutledge was convinced in the Everson case that the First Amendment was intended to make complete the separation between church and state; therefore, when it was incorporated into the Fourteenth Amendment, it prevented the state from paying bus fares of children to attend parochial schools or from authorizing the use of school time in school buildings for religious education. As previously indicated, he relied heavily on the writings of Jefferson and Madison, especially on Madison's Remonstrance. The enactment of a "Bill for Establishing Religious Freedom" in Virginia in 1786 , which had been sponsored originally by Jefferson and for which Madison led the successful fight against the opposition led by Patrick Henry, was in the judgment of Justice Rutledge the basis of the "establishment of religion" clause of the First Amendment. ${ }^{60}$ This clause was then intended to prevent aid to one religion or to all religions.

Justice Frankfurter in his $M c$ Collum opinion ${ }^{61}$ referred with approval to Justice Rutledge's dissent in the Everson case, and then proceeded to recount the history of the secularization of the public school prior to the adoption of the Fourteenth Amendment. He concluded that "by 1875 the separation of public education from church entanglements, of the State from the teaching of religion, was firmly established in the consciousness of the nation." should be determined not only with reference to the intention of the framers of the Amendment but also with reference to the development of the meaning which the language came to have in succeeding decades.

Counsel for the school board in the McCollum case argued persuasively that the clause did not have the broad meaning attributed to it by these justices. ${ }^{63}$ Counsel pointed out that eight members of the Virginia Senate objected to ratification of the Amendment because its meaning was too restricted, saying:

The third amendment recommended by Congress does not prohibit the rights of conscience from being violated or infringed; and although it goes to restrain Congress from passing laws establishing any national religion, they might, notwithstanding, levy taxes to any amount for the support of religion or its preachers; and any particular denomination of Christians might be so favored and supported by the general government, as to give it a decided advantage over the others, and in the process of time render it powerful and dangerous as if it was established as the national religion of the country. ${ }^{64}$

Counsel then set out in their brief the successive changes in language of the clause here in question, in all of which the emphasis certainly was on the prohibition against setting up a national religion. The language of the Amendment went

${ }^{\circ 0}$ Everson v. Board of Education, 330 U. S. r, 33-4r (r947).

${ }^{a 1}$ McCollum v. Board of Education, 333 U. S. 203, 212 (x948).

aId. at 217.

${ }^{03}$ Brief for Appellees in the McCollum case, pp. 24-101.1.

as Id. at 52-53, quoting from Journal of Virginia Senate, i789 6r-64 (r828). 
through the following evolution: "nor shall any national religion be established," "no religion shall be established by law, nor shall the equal rights of conscience be infringed," $"$ "Congress shall make no laws touching religion," make no law establishing religion, or to prevent the free exercise thereof, or to infringe the rights of conscience," respecting an establishment of religion, or prohibiting the free exercise thereof." Since the final draft was approved without debate in the House, ${ }^{60}$ it may be assumed that the changes amounted to differences in language without altering substantially the meaning. The first draft certainly was directed at the evils of an established church. It seems to me that it would be entirely reasonable to construe the clause as urged by the school board.

I find the historical arguments unconvincing. There seems to be no clear indication that the clause in question was intended to exclude all religious education in the schools of the country. Indeed, since the clause was applicable only to the National Government, which did not support schools, I feel quite certain that the application to the facts of the McCollum case was not within the contemplation of the Congress or of the states whose ratification incorporated the clause in the Constitution. ${ }^{70}$ That, of course, does not answer the constitutional question. It does, however, lead me to conclude that the question cannot be answered satisfactorily by attempting to discover what the language was intended to mean in $1789 .^{71}$

Other clauses of the First Amendment have been extended to new situations in recent years. Only in r940 was the freedom-of-speech protection thrown around picketing in a labor dispute. ${ }^{72}$ Although there is some doubt about the scope of that protection, ${ }^{73}$ it is clear that picketing is now considered "speech" or "press" for the purpose of the First Amendment. The power of a court to punish as contempt publication of articles critical of the court which are intended to influence the judge

${ }^{85}$ I ANnals of Cong. 434 (Gales ed., 1834).

es Id. at 729. See the debates on this version beginning on p. 729. "Mr. Madison said, he apprehended the meaning of the words to be, that Congress should not establish a religion, and enforce the legal observation of it by law, nor compel men to worship God in any manner contrary to their conscience." Id. at 730.
${ }^{67} \mathrm{Id}$. at 731 .
${ }^{88} 7 d$. at 766 .
SId. at 913 .

${ }^{30}$ See Corwin, The Supreme Court as National School Board, supra; Pfeffer, Religion, Edueation and the Constitution, 8 LAw. Gumd REv. 387 (1948). Pfeffer concludes that the historical debate is inconclusive. He points out that the defeat of the 1875 proposed amendment to the Constitution to limit the power of the states in using state funds for religious purposes was partly attributable to the belief that protection in staté constitutions was adequate. Id. at 393.

"In an editorial the American Bar Association fournal printed an immoderate criticism of the decision in the McCollum case. The editorial singled out the fact that Mrs. MfcCollum was an atheist secking the aid of the court and said: "Two hundred years ago, a woman like Mrs. McCollum would have been prosequted as an infidel and heretic. Today she sought and obtained the aid of a judicial decree to suppress the teaching which was the very genesis of the freedom which she exercises for herself by trying to take it away from others." The Journal resolves the historical conflict by accepting the construction of the First Amendment urged by the school board. 34 A. B. A. J. 482,483 (1948).

72 Thornhill v. Alabama, 310 U. S. 88 (1940).

${ }^{73}$ Picketing may be enjoined if there is a history of violence. Milk Wagon Drivers Union $v$. Meadowmoor Dairies, 312 U. S. 287 (I94I), or if there is no "economic nexus" between the labor dispute and the place picketed. Carpenters Union v. Ritter's Cafe, 315 U. S. 722 (1942). 
in the decision of a pending case has been greatly restricted. ${ }^{74}$ The basis of this limitation is, of course, an extension of the freedom of speech and of the press under the Amendment. A reading of the opinions in some of the Jehovah's Witnesses cases $^{75}$ will reveal the zealousness of the Court in protecting an unpopular minority in its right to the "free exercise" of its religion, and of its evangelistic activities. The reversal in the flag-salute case ${ }^{75}$ permitted the children of this sect to attend school without saluting the flag and repeating the pledge of allegiance, because these practices are contrary to their religious belief. In the restrictive covenant cases $^{77}$ another step was taken to extend constitutional rights of individuals, this time under the equal protection clause of the Fourteenth Amendment. The whole course of decision in recent years demonstrates that in the area of freedom of speech, press, and religion, the Court not only is unwilling to permit any presumption of constitutionality of state legislation but rather presumes that any action which might tend to interfere with these basic freedoms is unconstitutional. In the light of this doctrine, the McCollum case fits into the pattern. The Everson case is less understandable, for it appears to be a departure from the presumption.

Even though the McCollum case does conform to this sequence of decisions, there still remains the question of policy. Since briefs amici curiae were filed by the American Unitarian Association, the Synagogue Council of America and National Community Relations Advisory Council, The American Ethical Union, The Joint Conference Committee of the Southern Baptist Convention, The Northern Baptist Convention and The National Baptist Convention, the American Civil Liberties Union, and The General Conference of Seventh Day Adventists, in support of Mrs. McCollum, one might conclude that this "released time" movement was unpopular. Briefs supporting the school board were filed by the Attorney General of Illinois and by The Protestant Council of the City of New York. The weekday religious education program was not, however, an unpopular movement, for it has grown steadily through the years. The adoption by over 3000 communities in forty-six states denotes a popular appeal. The school boards and the parents in those communities believed that these classes contributed to the education of their children.

Complete secularization of the public school fails to provide an adequate education in the bases of our moral and ethical concepts. Religion does contribute at least these ideals to society. Probably never in the history of the world have these ideals been needed more-the lack of them has made of the world an armed camp,

"Bridges v. California, 3 I4 U. S. 252 (rg4I); Pennekamp v. Florida, 328 U. S. 33 I (I946); Craig v. Harney, 33 I U. S. 367 (1947).

${ }^{75}$ For example, the group of cases including Jones v. Opelika, Murdock v. Pennsyluania, etc., which are in 319 U. S. beginning at 103 (1943). This group of cases is especially interesting because they had been decided the other way the year before. The reversal came as the result of the resignation of Justice Byrnes and the appointment of Justice Rutledge. Jones v. Opelika, 3I6 U. S. 584 (r942).

${ }^{70}$ Board of Education v. Barnette, 319 U. S. 624 (1943), reversing Minersville School District v. Gobitis, 3 Io U. S. 586 (I940).

${ }^{77}$ Shelley v. Kraemer, 334 U. S. I (r948). 
and the "cold war" is an ever present reality. Tolerance, love of fellow men, kindness, responsibility for the welfare of others are values which should be kept before our children in the school years. The religious education classes make a contribution, however small, to that end.

On the other hand, classes in public schools which are segregated according to the religious preference of the parents do constitute a divisive force among the children. The child of one of my friends brought home from school a blank to be signed, requesting that the child be released from school to attend the religious education class. In discussing the proposal, the child asked this question: "Daddy, what is a Jew?" That question was prompted by the announcement that there would be separate classes for Jews in the system. Perhaps that question gave the father an opportunity to tell the child that the only difference is one of religion and to teach tolerance of the beliefs of others, but it may be that this division in the public school created in the mind of the child the notion that there is something different about Jews. If the latter be true, then it contributed to one of the serious ills of humanity. Thus sectarianism may defeat the main purpose of religious education in the schools. The various churches do wish to use the time to teach the religious ideas of the denomination or group. ${ }^{78}$ One of the principal objections is that the program will always be under the control of the dominant group in the community, and small and unpopular minorities will be excluded. For example, in the $M \bar{c}$ Collum case the evidence showed that the board opened the schools to any group, but the teacher and the curriculum would have to be approved by the Council of Religious Education. Further, the smaller sects could not afford to pay the expenses of separate classes. These factors prevent an equal opportunity to all and run counter to the fundamental assumption that the free public schools are available to all children in the community without any discrimination. There seem to be, therefore, strong policy arguments either to support or to challenge the decision in the McCollum case.

One of the principal criticisms of 'the case stems from its indefiniteness. Just what did the Court decide? The simple answer is that the system in the Champaign schools exceeded the constitutional authority of the state. One might conclude that the use of tax funds to assist the program was the controlling factor. Classes conducted outside the school buildings would then be lawful so long as no public money was used to assist. In the McCollum case the only financial aid given was in the preparation of the request cards and the use of heat and light of the school buildings. If this is the critical fact, then outside of school hours churches and religious groups could not be given permission to use school buildings, for even though a rental is paid the use does aid religion. Under such an interpretation the Y. M. C. A. in my university, which is tax supported, could not use the university

${ }^{78}$ In the McCollum case, the Protestant teacher testified that she tried to teach those elements common to all of the denominational groups. Her teaching would not have been satisfactory to the Jews nor to the Jehovah's Witnesses. 
auditorium for a vesper service. But in the sound-truck case, ${ }^{79}$ a Jehovah's Witness was using a public park for a religious speech and the state was held without power to prevent it. That is, not only may public property, presumably tax supported, be used for religious purposes, but its use for such purposes must be permitted. Certainly that is some aid to religion. I cannot conclude that the Court meant to eliminate entirely religious meetings in school buildings.

Another possibility is that the use of compulsory school attendance as a device to induce children to attend classes in religion made the Champaign program unlawful. Children are compelled by state law to attend school. During the assigned period they were released from regular classes to attend the religious education classes. If they did not attend those classes they were required to participate in other school work. They were satisfying their obligation to the state of compulsory school attendance while in the religious classes. I am convinced from the reports of the International Council of Religious Education that the compulsory attendance during school time is prized as one of the chief assets of the program, for it increases the number of children in the classes. One might argue, then, that the truant officer enforces attendance and that this feature is unlawful. The difficulty with this argument is that children may satisfy their obligation to attend school by their presence in a parochial school. Furthermore, a state may not require that the child secure his education in a public school. ${ }^{80}$ The very purpose of sending a child to a parochial school is to provide religious education. If the compulsory attendance feature of the McCollum case invalidates the program, it would seem that a child could not be compelled to attend any church school.

Justice Frankfurter in his concurring opinion made clear that not all "released time" religious education is outlawed. He found in the $M c$ Collum case enough factors to balance the scale against its validity. Does this mean that the court has now become a national school board?

Many other questions are raised by the Everson and $M c$ Collum cases. If the state cannot permit religious education in the public schools, and if it can buy the school books and pay transportation costs to attend a parochial school, may the state permit a school district to pay the tuition of a child to attend a parochial school? This constitutes aid to the child and not to religion. If the Constitution permits the payment of tuition, each church group will establish its own school (in communities where the church is sufficiently strong to get political support) and receive tax funds through the tuition payments of its pupils. If, however, the Constitution prohibits the payment of tuition to a church school, why can Congress provide for the payment of tuition and subsistence for a veteran who attends a church school to prepare for the ministry? Surely this aids religion in a very direct way. Under the G. I. Bill the tuition is paid to the school, and in some divisions of colleges

${ }^{70}$ Saia v. New York, 334 U. S. 558 (1948).

${ }^{80}$ Pierce v. Society of Sisters, 268 U. S. 5 I0 (I925). 
the tuition is high enough to afford a profit. ${ }^{81}$ The compulsory religious services at the Military and Naval Academies also aid religion. The armed services believe that religion preserves many values for soldiers, sailors, and marines, and provide chaplains who are classified according to their faiths. Men in the services during the late war reported that the chaplains made great contributions to the morale and effectiveness of the troops. However valuable this program, it does amount to government aid to religion, although no preference is accorded to any particular religion.

These examples are included to explain the bewilderment of school officials and their inability to determine the legality of school religious education classes which differ from the facts in the $M c$ Collum case. "Released time" programs are reported ${ }^{82}$ as continuing in New York, Indiana, Maine, South Carolina, New Jersey, and Virginia. A number of large city school systems have interpreted the decision to permit their plans to continue. ${ }^{83}$ The assumption is that the $M c$ Collum case only outlawed plans which make use of school buildings, school funds for the printing of cards, or the "machinery of operation" of the school system. If a parent may validly request that his child be excused from class to take a music lesson from a private teacher one-half hour weekly, these schools believe that the parent may likewise request that the child be permitted to attend a religious education class during school hours. The continuation of these classes accords little weight to that part of the Court's opinion which emphasized that the use of the compulsory school attendance in the McCollum case was one ground for the decision. The fact that many weekday religious education programs are being continued in spite of the decision evidences a strong desire in many communities to provide this educational experience for their school children.

I have been able to find references to only two cases on this question, one in Missouri and one in New York, decided since the McCollum case. ${ }^{84}$ In the report of the New York case, the judge stated that since at least five of the United States Supreme Court justices had said that "released time" programs were not unconstitutional per se, and since the New York plan differed substantially from the Champaign plan, he believed that the New York plan was valid. The Missouri court reached the opposite result. These decisions illustrate the difficulties facing state courts in interpreting the $\mathrm{McCollum}$ opinion.

The Champaign schools discontinued "released time" for the classes and the

${ }^{81}$ I have visited law schools for the American Bar Association which made a profit from student fees.

${ }^{82}$ McClure, They Want Weekday Religious Education, 25 INr't. J. Religrous Ed. 7 (Sept. 1948).

${ }^{83}$ Ibid. New York, Chicago, Cincinnati, Dayton, Toledo, Indianapolis, Boston, Pittsburgh, Minneapolis, St. Paul, Spokane, and Los Angeles.

${ }^{84}$ Balazs v. Board of Education of St. Louis, Circuit Court, St. Louis, Mo., decided May 25, I948. Cited by Pfeffer, Religion, Education and the Constitution, 8 LAw. Guild REv. 387,398 n. 138 (1948). The court held that the "released time" programs in St. Louis did not differ sufficiently to lcad to a different result. In New York a contrary result was reached in a suit begun by Joseph Lewis, President of the Freethinkers Society, who was plaintiff in the cases cited in note $5 \mathrm{r}$ supra. Lewis v. Spaulding, 193 Misc. 66, 85 N. Y. S. 2d 682 (Sup. Ct. Albany Co., Nov. 12, 1948). 
Council of Religious Education began a "free time" program after school hours. Interestingly enough, the Council rented a school room or two for the classes, indicating a belief of counsel for the board that the decision did not necessarily invalidate the use of school buildings for this purpose. I have no enrollment figures for the Champaign plan, but in the sister city of Urbana, where my children attend school, the after-school hours have not been as popular as were the "released time" hours. In Alabama ministers and laymen are developing a religious emphasis program in Pine Hill High School. Religion comes into the school through the regular courses, chapel lectures, and student forums. ${ }^{85}$ In Anderson, Indiana, the Council of Weekday Religious Education is continuing its classes in a mobile unit parked outside school buildings and in nearby churches. ${ }^{86}$ Apparently the Council interprets the McCollum case as applying primarily to the place of holding classes. These instances are illustrative of the community support for some kind of weekday religious education.

It is impossible to come to a clear-cut, rational conclusion on this subject. Although the movement for complete secularization of the schools had progressed a long way prior to Everson and McCollum, the line of decision, had been at best wavering, and even in the states with relatively specific constitutional provisions, some religion had been permitted in the public schools. The resort to history is equally unsatisfactory. Proponents of either view of the intention of the framers of the Amendment can find ample support. The language of the Constitution, however, is not static, but must be read in the light of the conditions existing at the time. The great guaranties of the First Amendment have been extended to new situations; so there has been a gain in individual freedom. If the freedom of religion includes freedom from religion, then the $\mathrm{McCollum}$ case is consistent with this development, but the Everson case deviates from the pattern.

A strong argument can be made that an education without religion gives a onesided picture of our society. The contributions of religion to morals and ethics cannot be measured. Since religion is encouraged by many devices, such as tax exemption of property used for religious purposes, that policy would be advanced by religious education in the schools. On the other hand, the segregation of children in the schools by sects divides and stimulates misunderstanding and hostility toward those of a different religion. As this stems from the public school system, which should serve as the primary agent in unifying our people, it discourages the very attitude of tolerance and charity it seeks to inculcate. I believe that the losses to our democratic society from classes so closely integrated into our public school system outweigh the gains to the children enrolled. This accords with the policy of extending freedom of speech and religion, for it makes religious education and worship depend on the free choice of the individual and leaves it

${ }^{86}$ N. Y. Times, April 18, I948, §I, p. 55, col. I.

${ }^{80}$ N. Y. Times, May 23, 1948, $\$$ r, p. 47 , col. I. 
uncoerced by the subtle compulsions which induce conformance to the group pattern. ${ }^{87}$

Surely the First Amendment, as incorporated in the Fourteenth, means at least that no state can use tax funds to support church schools directly. Compulsory attendance at a religious exercise would also seem to be forbidden. At the other extreme, undoubtedly the schools can teach the history of religion and religious ideas. It may be that the conflicts between these extremes could safely be left for solution at local levels. The court in the McCollum decision resolved the conflict for the Champaign School Board. I hope that in subsequent cases the meaning of the "establishment of religion" clause will be made clear.

${ }^{87}$ Note the quotation stupra note ro: "They want to go to the church with their schoolmates and ask their parents to sign release cards." 